\title{
What an International Branch Campus Is, and Is Not
}

\author{
A Revised Definition
}

\author{
Stephen Wilkins and Laura E. Rumbley
}

According to the Observatory on Borderless Higher Education (ОВнЕ) and the Cross-Border Education Research Team (C-BERT), there were 263 international branch campuses operating worldwide at the end of 2017. Although the international branch campus has become an established part of the cross-border higher education landscape - and definitions of this phenomenon have been elaborated by овне, С-веRт, and HESA (the United Kingdom's Higher Education Statistics Agency), there is still debate about what an international branch campus actually is.

In any scholarly field, researchers need to use the same terminology and definitions, otherwise meaning is subject to misunderstandings among readers, and comparisons of findings become, at least to an extent, pointless. Thus, clarifying what an international branch campus is, and is not, requires further attention.

During the last few years, the definition of international branch campuses used most often by researchers is C-BERT's, which was modified slightly in the November 2016 OBHE/C-BERT report on international branch campuses as follows:

An entity that is owned, at least in part, by a foreign education provider; operated in the name of the foreign education provider; and provides an entire academic program, substantially on site, leading to a degree awarded by the foreign education provider.

This definition has provided a sound point of departure for researchers. However, it omits certain key features that are vital to the essence of what a branch is, notably how the terms "branch" and "campus" are used in business and 
higher education. While international branch campuses are not generally considered businesses, they are parts of multinational enterprises (MNES), because the term "MNE" refers to any organization that engages in foreign direct investment (FDI) and operates in multiple countries. Business terms and concepts can help us make sense of what an international branch campus is, so that a clearer and more implementable definition may be developed.

The овнЕ/C-BERT definition of international branch campus not only omits certain key features, but it also specifies unnecessary criteria. In business, a bank, hotel, or retail company does not always offer exactly the same products and services at every branch; similarly, it seems unnecessary to insist that an overseas campus "provide an entire academic program" or one that "leads to a degree" in order to be categorized as an international branch campus. Indeed, there are a range of possibilities that might be considered. The programming offered to students enrolled in branch campuses should bear the name of the foreign institution, but should not encompass study abroad centers, which are intended mainly to provide a short-term study experience for students from the institution's home campus.

\section{2 Core Features}

A refined understanding of international branch campuses recognizes several core features, as described below.

- Ownership, a key criterion: International branch campuses are owned, at least partially, by a specific foreign higher education institution. Foreign-backed institutions like the American University of Beirut or the British University in Dubai are not international branch campuses since these are typically private institutions that have adopted a foreign higher education system, which often involves accreditation by foreign organizations. Confederations or educational systems, like Islamic Azad University, which has four campuses outside Iran, should also not be considered as branch campuses, since there is no clear "parent" campus.

- The bottom line matters: MNEs make investments in foreign countries, typically to establish operations in these countries. If the home institution earns only a fixed fee or a commission based on student enrollments, then it is clear that the home institution does not truly "own" the foreign operation, and it is not a branch campus.

- Substantive control is crucial: The home institution may not actually own the land or premises from which the branch operates, but it does own the brand name, and it is responsible for curricula and accrediting awards. 
Although host country governments may provide the financial investment needed to establish branch campuses - as Abu Dhabi did for New York University and Paris-Sorbonne - when a true branch campus is established, the parent institution has control, at least to some extent, over strategic decisions such as scale of operations, curricula, and faculty appointments. It is also responsible for academic standards and quality assurance.

- Partnerships: If a foreign campus is really an international branch campus, it will be recognized as such on the websites of the home and branch institutions. For example, Westminster University's website refers to Westminster International University in Tashkent as a partner institution, not a branch campus. Similarly, Xi'an Jiaotong-Liverpool University in China and YaleNUS College in Singapore, which both resulted from partnerships, are not described by any of the founding institutions as a branch campus. However, some branch campuses do have a partnership ownership structure. Partners may be private entrepreneurs, for-profit companies, or not-for-profit organizations. For example, Heriot-Watt's campus in Dubai is jointly owned with a company called Study World. Profits resulting from the campus's operations are shared between the two organizations.

- The need for a campus: Finally, to be recognized as a branch campus, the institution's infrastructure should fit with the definition of a campus. The word "campus" refers to the grounds and buildings of an educational institution and suggests that students receive a certain study experience. However, many universities run foreign outposts that offer only a single qualification, or a very small number of qualifications, operating from a handful of rooms in an office block, while others employ no full-time faculty in the host country. At a minimum, students at a branch campus should have access to a library, an open access computer lab, and dining facilities.

\section{Revised Definition, and Moving Forward}

This refined understanding of international branch campuses suggests a new working definition for the field, which speaks to the key elements that should ideally frame the phenomenon:

An international branch campus is an entity that is owned, at least in part, by a specific foreign higher education institution, which has some degree of responsibility for the overall strategy and quality assurance of the branch campus. The branch campus operates under the name of the foreign institution and offers programming and/or credentials that bear 
the name of the foreign institution. The branch has basic infrastructure, such as a library, an open access computer lab, and dining facilities, and, overall, students at the branch have a similar student experience to students at the home campus.

Transnational higher education operates in a myriad of forms and modes. Although this article has identified some of the core features of an international branch campus, these campuses are far from homogenous. For example, shared campuses exist in countries such as Malaysia and the United Arab Emirates, where multiple institutions share infrastructure such as catering and sports facilities. Thus, while our proposed definition may be an improvement over existing definitions, a degree of personal judgment will still always be needed to classify certain campuses.

\section{Acknowledgement}

This chapter was previously published in International Higher Education, No. 96, Winter 2019 (pp. 12-14). Reprinted here with permission. 